\title{
Lipid yields from oleaginous yeasts isolated from the north Peruvian Andes by culture media non-limiting nitrogen
}

\author{
Méndez Polo César Alexander \\ Escuela de Microbiología y Parasitología, Universidad Nacional de Trujillo, Perú \\ Quiroz Rodríguez Freddy Jonathan \\ Escuela de Ingeniería Agroindustrial, Universidad Nacional de Trujillo, Perú \\ Soriano Bernilla Bertha Soledad \\ Departamento de Microbiología y Parasitología. Laboratorio de Biomoléculas. Universidad \\ Nacional de Trujillo, Perú \\ Rojas-Padilla Carmen Rosa \\ Departamento de Ciencias Agroindustriales. Laboratorio de Biomoléculas. Universidad Nacio- \\ nal de Trujillo, Perú

\section{Vásquez-Villalobos Víctor Javier*} \\ Departamento de Ciencias Agroindustriales. Laboratorio de Biomoléculas. Universidad Nacio- \\ nal de Trujillo, Perú
}

*Corresponding author. Email: vvasquez@unitru.edu.pe

\section{Article Info}

https://doi.org/10.31018/

jans.v13i2.2670

Received: April 15, 2021

Revised: May 24, 2021

Accepted: May 29, 2021

\section{How to Cite}

Alexander, M.P.C. et al. (2021). Lipid yields from oleaginous yeasts isolated from the north Peruvian Andes by culture media non-limiting nitrogen. Journal of Applied and Natural Science, 13(2), 607 - 615. https://doi.org/10.31018/jans.v13i2.2670

\begin{abstract}
Oleochemicals can be obtained from oily yeasts due to their ability to produce a high lipid content. This research aimed to isolate them from the North Peruvian Andes with a lipid content greater than $20 \%$. They were identified by sequencing internal transcribed spacer regions ITS of conserved ribosomal DNA (rDNA), evaluate their growth kinetics, biomass and lipid yields, using culture media with $\mathrm{C} / \mathrm{N}$ 100:1+xylose (MS-1-7) and 2:1+glucose (MS-2-7). Growth kinetics up to the maximum stationary phase was evaluated using the parameterized Gompertz type II model. Rhodotorula glutinis, $R$. mucilaginosa, and $R$. kratochvilovae were selected. The $\mathrm{C} / \mathrm{N}$ ratio in the culture medium influenced growth kinetics, biomass and lipids yields. With MS-1-7, a high specific growth rate $\left(\mu_{\max }\right)$ was obtained, reaching the stationary phase between 6 to $9 \mathrm{~h}$ and the highest lipid accumulation between $23.1 \%$ and 31.5\%. With the MS-2-7 medium, maximum biomass value obtained in the stationary phase between 37 and $51 \mathrm{~h}$, which generated the highest biomass yields at the end of the entire process and lipid yield of $4.65,5.59$, and $8.80 \mathrm{~g} \mathrm{~L}^{-1}$ in the strains mentioned. There is potential to obtain high lipid yields using a culture media non-limiting nitrogen, examining not only the $\mathrm{C} / \mathrm{N}$ ratio. But also, the quantities, nature of the components, and type of oleaginous yeasts taking care to avoid a high carbon concentration to prevent the Cabtree effect.
\end{abstract}

Keywords: Lipid yield, Limiting and Non-limiting nitrogen, Rhodotorula glutinis, Rhodotorula mucilaginosa, Rhodotorula kratochvilovae

\section{INTRODUCTION}

Oleochemicals are products derived from green chemistry. They are obtained from renewable raw materials, with a low level of potential hazards, which generate common toxicity substances. Their long chains and double bonds produce transesterification, epoxidation, amidation, and amination reactions (Zarli, 2020). Their growing economic potential is found in the markets for food, personal care, detergents, cosmetics, pharmaceuticals, medicals, paints, resins, emulsifiers, plasticizers, biolubricants, biodiesel, and jet fuel (Spagnuolo et al., 2019; Maina et al., 2016). This demand is related to population growth and the interest in using products based on renewable and biocompatible resources (Zarli, 2020). There are also limitations on agricultural land expansion and concerns and environmental policy changes (OECD-FAO, Agricultural Out- 
look 2015-2024) (Adrio, 2017). It is possible to obtain lipids or chemical oils sustainably by microbial synthesis, whose traditional production is based on raw materials of vegetable oils and fats. Oleaginous yeasts can synthesize them using glucose, xylose, L-arabinose, $\mathrm{CO}_{2}$, methane, or methanol (Zhang et al., 2021). These are the most promising microorganisms in the production of the high content of cellular lipids. Compared to microalgae, molds, and bacteria, they can accumulate more than $70 \%$ of their biomass due to their high growth rate, productivity, and low areas required for production since they can be grown in bioreactors under controlled conditions (Vasconcelos et al., 2019). Also, it can be used as raw material to produce biodiesel and adapted to the production of nutraceuticals using metabolic engineering (Dey and Maiti, 2013; Patel et al., 2020). Also, can provide sustainable production of oleochemicals. They synthesize and accumulate lipids, primarily as triacylglycerides (Adrio, 2017). Besides using pure sugars as a substrate, it also can use waste rich in sugars (molasses and cheese whey), lignocellulosic materials, glycerol derived from biodiesel, starch, etc., residues from food processing (Maina et al., 2016). Hydrolysis of lignocellulosic materials as pentoses and hexoses can be obtained (Maina et al., 2016).

Different species of yeasts with oleaginous backgrounds of the genus Candida, Cryptococcus, Rhodo sporidium, Rhodotorula have been found in the Arctic and Antarctica, at temperatures below $-20^{\circ} \mathrm{C}$. Also, in coniferous forests in European Alps, Mont Blanc (4 810 m.a.s.I.) (Buzzini et al., 2012; Zalar and GundeCimerman, 2014; Yurkov et al., 2012).

The main barrier for the industrial production of lipids is the cost at the fermentation stage, therefore adjusting it to an oleaginous system is imperative to obtain a higher yield (Karamerou and Webb, 2019). In this context, it has been reported that with a high $\mathrm{C} / \mathrm{N}$ ratio of 84.9 , 211.0, 76.9 using crude glycerol and glucose as a carbon source, high lipid contents in the cellular biomass of $54.3 \%, 65.1 \%, 45.51 \%$ respectively has been obtained with Lipomyces starkeyi, Rhodosporidium turoloides, and Yarrowia lipolytica. It is crucial to avoid a high $\mathrm{C} / \mathrm{N}$ ratio that implies a high substrate concentration, producing growth inhibition and a fall in cell and lipid yield (Christophe et al., 2012).

Also, it was reported that, due to the nitrogen limitation caused by an increase in carbon in the culture medium, high content of cellular lipids is produced in yeasts. Still, on the other hand, lower production of cellular biomass occurs, converting the carbon source by biosynthesis into storage lipids (Ratledge, 2002). Thus, some species can accumulate lipids up to $70 \%$ of their biomass dry weight (Papanikolaou and Aggelis, 2011). Studies carried out with the oleaginous yeasts Cryptococcus curvatus have shown that when is cultivated in lactose and sucrose with limited nitrogen, there is an accumulation of a large amount of total intracellular sugars of up to $68 \%$ in the initial stage of fermentation, which decreases to $20 \%$ at the end (Tchakouteu et al., 2014). The high content of lipids with deficiency or nitrogenfree has been found in 35 species of oleaginous yeasts. An increase in the $\mathrm{C} / \mathrm{N}$ molar ratio from 150 to 350 increases the conversion efficiency of glucose to lipid in Rhodotorula glutinis from 0.25 to 0.40 , but it has detrimental effects on cell viability. An exception to this is Cryptococcus terricola, which accumulates lipids during logarithmic growth instead of doing it later, and in the presence of excess nitrogen (Sitepu et al., 2013; Sitepu et al., 2014). Regardless of the carbon source, higher $\mathrm{C} / \mathrm{N}$ ratios increase lipid yields in $R$. toruloides but decrease the specific growth rate (Lopes et al., 2020). A C/N ratio greater than 20 stimulates lipid biosynthesis in oleaginous yeasts without producing a significant increase in biomass (Kot et al., 2019). This research aimed to isolate oleaginous yeasts from the North Peruvian Andes with a lipid content greater than $20 \%$. Identify them, evaluate their growth kinetics, biomass and lipid yields using culture media with $\mathrm{C} / \mathrm{N}$ 100: 1 with xylose as carbon source, limiting nitrogen; and 2:1 with glucose as carbon source, non-limiting nitrogen.

\section{MATERIALS AND METHODS}

This study was carried out at the Biomolecules Laboratory, Agroindustrial Science Department, National University of Trujillo, Peru.

\section{Equipment}

Vertical autoclave, drying stove $1400 \mathrm{~W}$; analytical balance $205 \mathrm{~g}$ with precision $0.0001 \mathrm{~g}$; centrifuge 6000 rpm; optical microscope 40x; orbital shaker incubator four at $70{ }^{\circ} \mathrm{C}, 40-400 \mathrm{rpm}$; sonicator/ultrasonic bath 45 $\mathrm{kHz}$ with heater and temperature control $\pm 3{ }^{\circ} \mathrm{C}$; vortex mixer 2850 rpm; UV-C camera; multifunction gas extractor; Neubauer chamber.

\section{Reagents}

Xylose, anhydrous glucose, peptone, yeast extract, agar, magnesium sulfate heptahydrate $\mathrm{MgSO}_{4} \cdot 7 \mathrm{H}_{2} \mathrm{O}$, sodium chloride $\mathrm{NaCl}$, calcium chloride $\mathrm{CaCl}_{2}$, ammonium sulfate $\left(\mathrm{NH}_{4}\right)_{2} \mathrm{SO}_{4}$, monopotassium phosphate $\mathrm{KH}_{2} \mathrm{PO}_{4}$, chloramphenicol, citric acid $\mathrm{C}_{6} \mathrm{H}_{8} \mathrm{O}_{7}$, phosphate sodium $\mathrm{Na}_{2} \mathrm{HPO}_{4}$, glycerol $\mathrm{C}_{3} \mathrm{H}_{8} \mathrm{O}$, formaldehyde $\mathrm{CH}_{2} \mathrm{O}$, absolute ethanol $\mathrm{C}_{2} \mathrm{H}_{5} \mathrm{OH}$, petroleum ether, methylene blue.

Fig. 1 shows the sequence for isolation, treatment with ultrasound, and heat to determine the lipid content, molecular identification, and cultures obtained to evaluate growth kinetics in shake flasks, dry weight biomass yield, and lipids in oleaginous strains. 


\section{Yeast isolation}

Yeasts were isolated from nearby forests of the Porcon farm - Cajamarca, Peru ( $7^{\circ} 02^{\prime} 10.69 " \mathrm{~S} 78^{\circ} 38^{\prime} 04.39 "$ W, 3148.5 m.a.s.l.; $7^{\circ} 02^{\prime} 32.66^{\prime \prime}$ S $78^{\circ} 38^{\prime} 28.87^{\prime \prime}$ W, 3 303.4 m.a.s.I.) and the El Paraiso forests - La Libertad, Peru (8 00' 07.25" S 78 27' 51.27" W, 3398 m.a.s.I.). Approximately $20 \mathrm{~g}$ were taken per soil sample from random points forming a triangle at the sampling site, placed in ziplock bags. The samples were stored in refrigerators at $4{ }^{\circ} \mathrm{C}$. From each homogenized sample, $1 \mathrm{~g}$ was taken, which was supplemented with an enrichment medium of composition $\left(\mathrm{g} \mathrm{L}^{-1}\right)$ : glycerol 100 , $\left(\mathrm{NH}_{4}\right)_{2} \mathrm{SO}_{4} 1, \mathrm{KH}_{2} \mathrm{PO}_{4} 1, \mathrm{MgSO}_{4} .7 \mathrm{H}_{2} \mathrm{O} 0.5$, yeast extract 0.5 . They were incubated at $30{ }^{\circ} \mathrm{C}$ and shaking at $150 \mathrm{rpm}$ for $48 \mathrm{~h}$. Serial dilutions of the enrichment medium were made up to $10^{-5}$ and $10^{-6}$. These dilutions were seeded onto a surface in sterile Petri dishes (previously dried at $20^{\circ} \mathrm{C}$ for $12 \mathrm{~h}$ ) with selective medium (SM-1) solid C/N 100: 1 and incubated at $30^{\circ} \mathrm{C}$ for $96 \mathrm{~h}$. The SM-1 composition $\left(\mathrm{g} \mathrm{L}^{-1}\right)$ was: xylose 20 , $\left(\mathrm{NH}_{4}\right)_{2} \mathrm{SO}_{4} 5, \mathrm{KH}_{2} \mathrm{PO}_{4} 1, \mathrm{MgSO}_{4} .7 \mathrm{H}_{2} \mathrm{O} 0.5$, yeast extract 0.5 , agar 20 , distilled water $1000 \mathrm{~mL}$, chloramphenicol 0.05 . The yeasts obtained were streaked again in SM-1 to get morphologically pure cultures incubated at $30{ }^{\circ} \mathrm{C}$ for $96 \mathrm{~h}$. A yeast colony was selected at random, and simple staining with methylene blue was performed and observed under a microscope to verify its morphology. The cultures obtained were kept refrigerated at $4{ }^{\circ} \mathrm{C}$.

\section{Form of calculation of the carbon-nitrogen ratio (C/} N).

The carbon-nitrogen 2:1 ratio (Equation 1) was calculated taking glucose as a carbon source $\left(20 \mathrm{~g} \mathrm{~L}^{-1}\right)$, the nitrogen content of peptone $\left(20 \mathrm{~g} \mathrm{~L}^{-1}\right)$, and yeast ex-

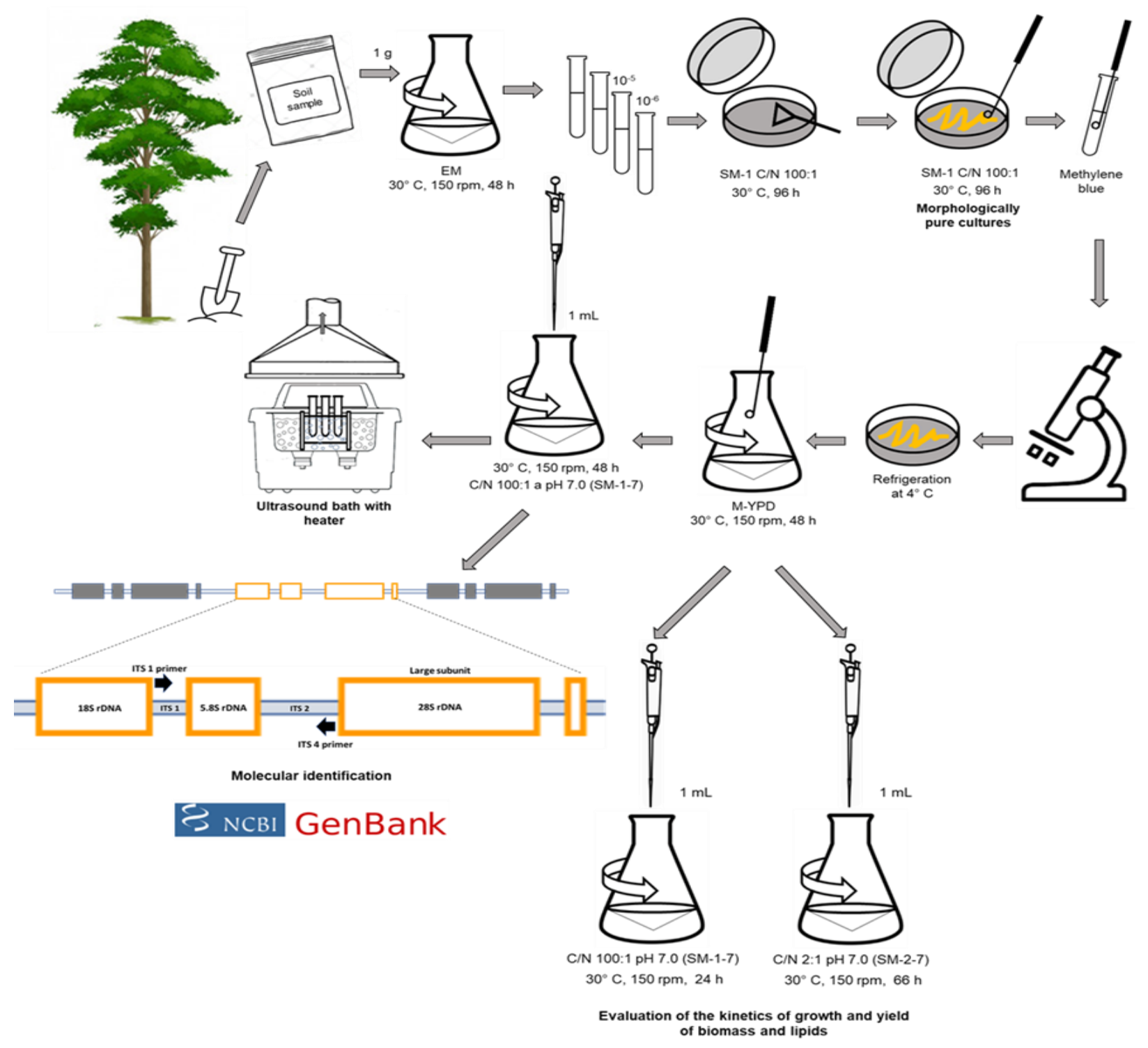

Fig. 1. Schematic flow diagram for the isolation of oleaginous yeasts, treatment to determine lipid content, molecular identification and obtaining cultures to evaluate growth kinetics and biomass and lipid yield. 
tract $\left(10 \mathrm{~g} \mathrm{~L}^{-1}\right)$, where $40 \%$ is the percentage of carbon contained in glucose, $14.7 \%$, and $10.5 \%$ is the percentage of nitrogen contained in peptone and yeast extract respectively. The carbon-nitrogen 100:1 ratio (Equation 2) was calculated by taking xylose as a carbon source $\left(20 \mathrm{~g} \mathrm{~L}^{-1}\right)$. The nitrogen content was taken from ammonium sulfate $\left(0.762 \mathrm{~g} \mathrm{~L}^{-1}\right), 40 \%$ of the carbon in xylose, and $21 \%$ of the nitrogen in ammonium sulfate.

$\mathrm{C} / \mathrm{N}=$ Glucose $\left(\mathrm{g} \mathrm{L}^{-1}\right) * 20 * 40 \% /$ Peptone $\left(\mathrm{g} \mathrm{L}^{-1}\right) * 20$ $* 14.7 \%+$ yeast extract $\left(\mathrm{g} \mathrm{L}^{-1}\right) * 10 * 10.5 \%=2: 1$

(Eq.1)

$\mathrm{C} / \mathrm{N}=$ Xylose $\left(\mathrm{g} \mathrm{L}^{-1}\right) * 20 * 40 \% /$ Ammonium sulphate $\left(\mathrm{g} \mathrm{L}^{-1}\right) * 0.762 * 21 \%=100: 1$

\section{Selection}

The material was taken with a Kolle handle loop from each isolated sample and seeded by manual shaking in flasks with medium (M-YPD), incubating at $30{ }^{\circ} \mathrm{C}$ with a shaking of $150 \mathrm{rpm}$ for $48 \mathrm{~h}$. The M-YPD (yeast extract peptone dextrose) had the composition $\left(\mathrm{g} \mathrm{L}^{-1}\right)$ : yeast extract 10 , peptone 20 , glucose $20,1000 \mathrm{~mL}$ distilled water. Next, $1 \mathrm{~mL}$ of the samples enriched in M-YPD were added to the flasks with medium $\mathrm{C} / \mathrm{N} \mathrm{100:1} \mathrm{at} \mathrm{pH}$ 7.0 (SM-1-7) and incubated at $30^{\circ} \mathrm{C}$ with a shaking of $150 \mathrm{rpm}$ for $48 \mathrm{~h}$. The composition $\left(\mathrm{g} \mathrm{L}^{-1}\right)$ of the SM-1-7 medium was: xylose $40 \% 100 \mathrm{~mL}$ (400 g of xylose in 1 $000 \mathrm{~mL}$ of water), $\left(\mathrm{NH}_{4}\right)_{2} \mathrm{SO}_{4} \quad 0.762, \mathrm{NaCl} 0.1$, $\mathrm{MgSO}_{4} .7 \mathrm{H}_{2} \mathrm{O} 0.5, \mathrm{CaCl}_{2} 0.1$, yeast extract 0.1 , citrate phosphate buffer $900 \mathrm{~mL}$ (citric acid solution $741.15 \mathrm{~mL}$ and bibasic sodium phosphate solution $158.85 \mathrm{~mL}$.

\section{Determination of lipid content}

In MS-1-7 medium, $12 \mathrm{~mL}$ of the yeast culture was taken and added to previously weighed capped tubes. They were centrifuged at $3000 \mathrm{rpm}$ for $10 \mathrm{~min}$, discarding the supernatant. The tubes, without caps, with yeast biomass, were dried at $50{ }^{\circ} \mathrm{C}$ for 48 hours, then the tubes were capped and weighed, and determined the initial dry biomass, expressed as $\mathrm{g} \mathrm{mL}^{-1}$. Next, $5 \mathrm{~mL}$ of $5 \%\left(\mathrm{NH}_{4}\right)_{2} \mathrm{SO}_{4}$ solution was added, placing it on ice for 2 minutes, then placed in an ultrasound bath for 2 minutes at $25^{\circ} \mathrm{C}$ and $45 \mathrm{kHz}$. It was centrifuged at 3 $000 \mathrm{rpm}$ for 5 minutes; discarded the supernatant. Added $3 \mathrm{~mL}$ of absolute ethanol, shaken vigorously on agitator vortex for 5 seconds, then $1.25 \mathrm{~mL}$ of chloroform and $1.25 \mathrm{~mL}$ of petroleum ether were added, and then shaken in the vortex for 10 seconds. The tubes were then centrifuged at $3000 \mathrm{rpm}$ for $10 \mathrm{~min}$. Then placed in a water bath equipped with a multifunction gas extractor for 2 hours at $50{ }^{\circ} \mathrm{C}$. Subsequently, they were placed in an oven at $50{ }^{\circ} \mathrm{C}$ for $96 \mathrm{~h}$ to determine the final dry biomass. Equation 3 determined the percentage of the lipid content:

(Initial dry biomass - final dry biomass) / (Initial dry biomass) $\times 100$

(Eq. 3)
Samples with a lipid content greater than $20 \%$ were seeded in solid M-YPD medium and kept refrigerated at $4{ }^{\circ} \mathrm{C}$.

\section{Molecular identification}

Amplification of the genetic material of the sequences of internal transcribed spacer regions ITS of conserved ribosomal DNA (rDNA) was carried out using the Sanger technique. The analysis was limited to identifying the sequence similarities of the ITS regions (Gientka et al., 2017).

Form of evaluation of the kinetics of growth of oleaginous yeasts in MS-1-7 and MS-2-7 media

Material with a Kolle handle loop was taken from each isolated strain and seeded by manual shaking in flasks with M-YPD medium and incubated with shaking at 150 rpm at $30{ }^{\circ} \mathrm{C}$ for $48 \mathrm{~h}$. Enriched samples $(1 \mathrm{~mL})$ was taken and added to $50 \mathrm{~mL}$ flasks with MS-1-7 and MS-2 -7 media, both at $\mathrm{pH}$ 7.0. The media were then incubated at $30{ }^{\circ} \mathrm{C}$ with shaking at $150 \mathrm{rpm}$ for 24 and $66 \mathrm{~h}$, respectively. Yeast growth was quantified at $1 \mathrm{~h}$ intervals using the Neubauer chamber and 40X light microscopy. The Gompertz type II parameterized model contrasted the growth (Tjørve and Tjørve, 2017) (Equation 4):

$$
\mathrm{Y}=\operatorname{Aexp}\left[-\exp \left(\mathrm{b}-\mathrm{K}_{\mathrm{G}} \mathrm{t}\right)\right]
$$

Where: $Y: \log \left(N / N_{0}\right), N$ is the number of yeasts (cells $\mathrm{mL}^{-1}$ ) as a function of time $t(h)$ and $N_{0}$ is the number of initial yeasts (cells $\mathrm{mL}^{-1}$ ) at time $t=0 \mathrm{~h}$. $A$ is the upper asymptote (absolute maximum growth value), $b$ is a constant, $\mathrm{K}_{\mathrm{G}}$ is the coefficient of the growth rate. With the use of Software R v.3.6.1., the growth curves were plotted and the parameters were determined as follows: specific growth speed $h^{-1}\left(\mu_{\max }=A^{*} b\right)$, latency phase $h$ $\left(\lambda=(b-1) / K_{G}\right)$ and generation time $h\left(G=\ln 2 / \mu_{\max }\right)$.

\section{Oil yeast lipid yield in MS-1-7 and MS-2-7 media.} After 24 hours of growth in MS-1-7 medium, $66 \mathrm{~h}$ in MS -2-7 medium, evaluated the lipid content following the procedures described above and their yield.

\section{RESULTS}

\section{Isolation and selection of yeasts for lipid content}

Three strains were selected from 18 cultures obtained from samples taken in the geographical areas of the North Peruvian Andes. The strains were isolated from nearby forests of the Porcon farm - Cajamarca: CON-5 and POR-3 and EI Paraiso forests - La Libertad: EP-5, with lipid content of $31.5 \%, 29.7 \%$, and $23.1 \%$, respectively.

\section{Molecular identification}

The ITS regions of the rDNA of the yeast strains encod- 
ed as CON-5, EP-5, and POR-3, were identified: Rhodotorula glutinis, Rhodotorula mucilaginosa, and Rhodotorula kratochvilovae, respectively. The primers 5'-3' ITS1 (TCCGTAGGTGAACCTGCGG) and ITS4 (TCCTCCGCTTATTGATATGC) were used to identify which were incorporated into Genbank as LC413754.1; MK215798.1, and LC390313.1, respectively.

Evaluation of the growth kinetics of oleaginous yeasts in MS-1-7 (C/N 100: 1) and MS-2-7 (C/N 2: 1) media

In Fig. 2, 3, and 4, the growth of the three strains of Rhodotorula (glutinis, mucilaginosa,

and kratochvilovae) observed in MS-2-7 medium (C/N 2:1) took a long time to reach a higher value of cellular biomass $A(\log N / \mathrm{No})$, compared to that obtained with the MS-1-7 medium (C/N 100:1). The three strains of Rhrodotorula in MS-2-7 were determined to reach

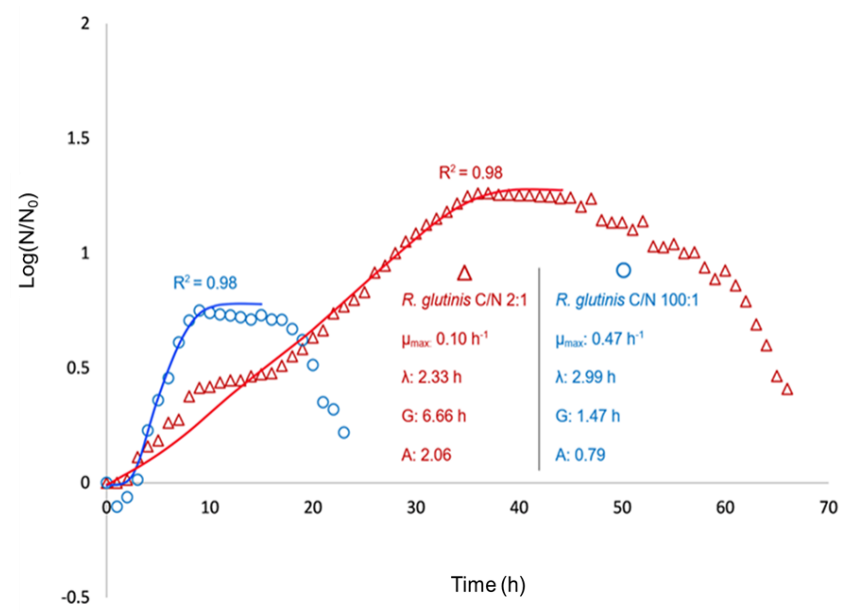

Fig. 2. Growth curve of $R$. glutinis in the culture media MS-2-7 and MS-1-7 with C/N 2:1 and C/N 100:1 ratios, respectively.

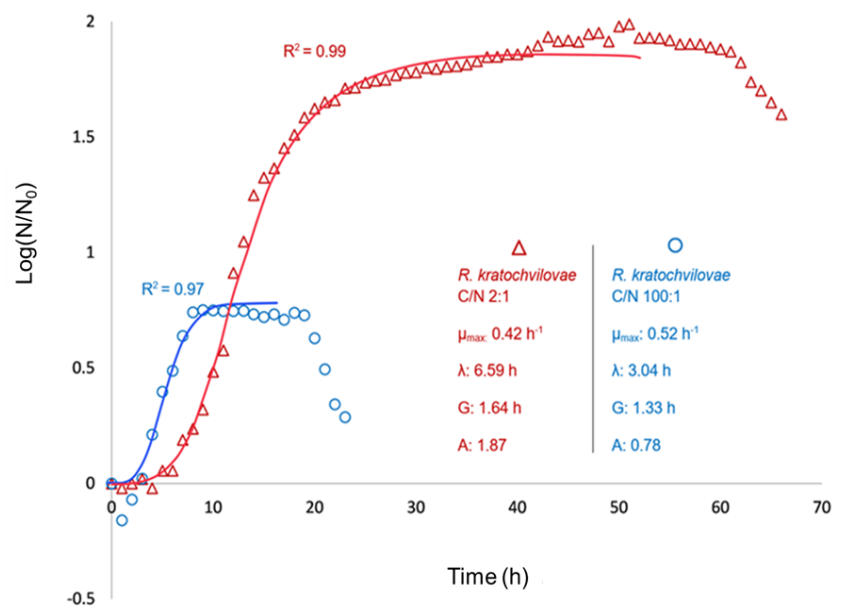

Fig. 4. Growth curve of $R$. kratochvilovae in the culture media MS-2-7 and MS-1-7 with C/N 2:1 and C/N 100:1 ratios, respectively. their maximum value of $A$ at 37,39 , and $51 \mathrm{~h}$, values higher than 9, 6 and $9 \mathrm{~h}$ obtained in MS-1-7.

Similarly, Fig. 2, 3, and 4 show the curves modeled with the parameterized Gompertz type II model for the growth of the three Rhodotorula strains up to a maximum stationary phase, in the media with $\mathrm{C} / \mathrm{N} 2: 1$ and $\mathrm{C} / \mathrm{N}$ 100:1, with their respective kinetic parameters indicating statistical consistency of the model with $R^{2}$ values between $97 \%$ and $99 \%$. The three strains of Rhodotorula showed a lower value of $\mu_{\max }$, higher values of $A$ and $G$ using the medium MS-2-7 (C/N 2:1) compared to MS-1-7 medium (C/N 100:1) was used. Regarding the duration of $\lambda, R$. glutinis in medium with a $\mathrm{C} / \mathrm{N}$ ratio of $2: 1$ was $2.33 \mathrm{~h}$, less than the $\lambda$ of $2.99 \mathrm{~h}$ obtained in medium with $\mathrm{C} / \mathrm{N}$ ratio of 100:1. For $R$. mucilaginosa and $R$. kratochvilovae, the values were the opposite, since $R$. mucilaginosa and $R$. kratochvilovae in medium with $\mathrm{C} / \mathrm{N} 2: 1$ ratio presented $\lambda$ of 3.98 and $6.59 \mathrm{~h}$ respectively, while in medium with $\mathrm{C} / \mathrm{N}$

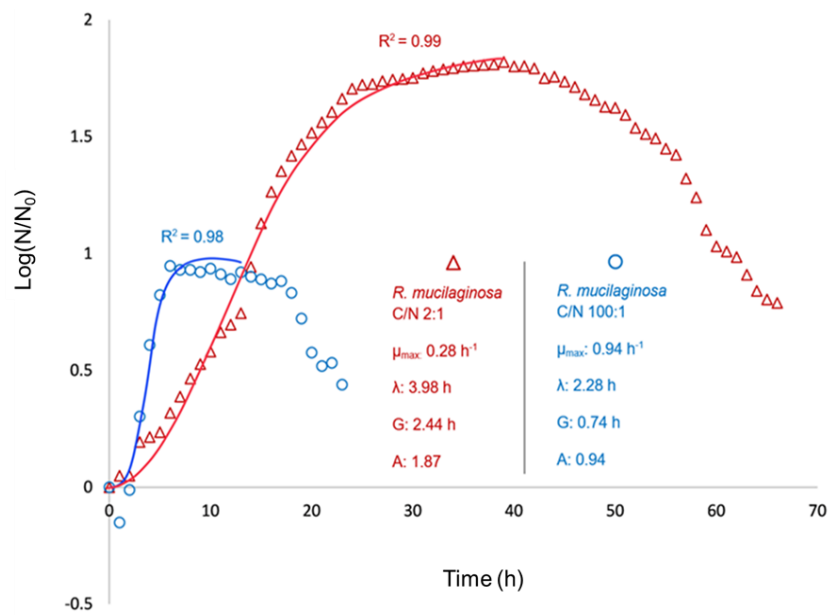

Fig. 3. Growth curve of $R$. mucilaginosa in the culture media MS-2-7 and MS-1-7 with C/N 2:1 and C/N 100:1 ratios, respectively.

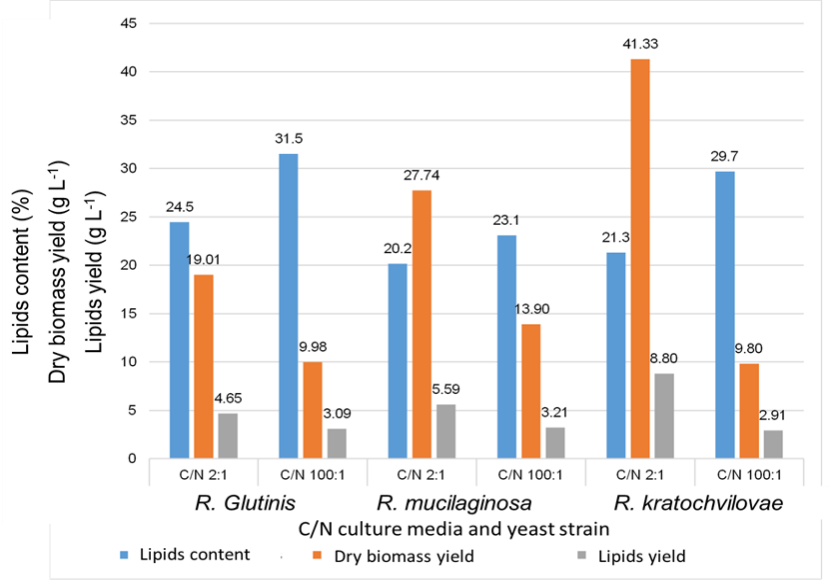

Fig. 5. Lipid content, dry biomass and lipid yields in the three Rhodotorula strains using culture media with $\mathrm{C} / \mathrm{N}$ 2:1 and 100:1. 
ratio $100: 1$ presented a lower value of $\lambda$, which was 2.28 and $3.04 \mathrm{~h}$ respectively.

Lipid yield with MS-1-7 (C/N 100:1) and MS-2-7 (C/N 2: 1) media. Fig. 5 shows the behavior of the three Rhodotorula strains in the culture media with $\mathrm{C} / \mathrm{N}$ ratios $2: 1$ and $100: 1$. Strains in medium with a $\mathrm{C} / \mathrm{N}$ ratio of $100: 1$ obtained a higher percentage of lipids, of $31.5 \%, 23.1 \%$, and $29.7 \%$; compared to values lower than $24.5 \%, 20.2 \%$, and $21.3 \%$ obtained with a medium with a $\mathrm{C} / \mathrm{N}$ ratio $2: 1$, for $R$. glutinis (CON-5), $R$. mucilaginosa (EP-5) and R. kratochvilovae (POR-3) respectively.

On the other hand, contrary to the medium with a $\mathrm{C} / \mathrm{N}$ ratio of 2: 1 , they presented higher values of biomass and lipid yields of the order of $19.01 \mathrm{~g} \mathrm{~L}^{-1}, 27.74 \mathrm{~g} \mathrm{~L}^{-1}$, and $41.33 \mathrm{~g} \mathrm{~L}^{-1}$; as well as $4.65 \mathrm{~g} \mathrm{~L}^{-1}, 5.59 \mathrm{~g} \mathrm{~L}^{-1}$, and $8.80 \mathrm{~g} \mathrm{~L}^{-1}$. This result compared to the medium with a $\mathrm{C} / \mathrm{N}$ ratio $100: 1$ with lower values of biomass and lipid yields $9.98 \mathrm{~g} \mathrm{~L}^{-1}, 13.90 \mathrm{~g} \mathrm{~L}^{-1}$, and $9.80 \mathrm{~g} \mathrm{~L}^{-1}$; as well as $3.09 \mathrm{~g} \mathrm{~L}^{-1}, 3.21 \mathrm{~g} \mathrm{~L}^{-1}$, and $2.91 \mathrm{~g} \mathrm{~L}^{-1}$ for R. glutinis (CON $-5), R$. mucilaginosa (EP-5) and $R$. kratochvilovae (POR-3) respectively.

\section{DISCUSSION}

The three selected cultures showed a greater than $20 \%$ lipid content, which is the minimum content required to be considered oleaginous yeast (Ageitos et al., 2011). The sampled areas were chosen based on the evidence that Rhodosporidium and Rhodotorula, generally known as potential lipid producers, have an important role as saprophytes or parasites in coniferous and deciduous forests (Sláviková and Vadkertiová, 2000; Buzzini et al., 2012; Yurkov et al., 2012) and alluvial soils (Wuczkowski and Prillinger, 2004). Also, based on the evidence of resisting temperatures below $-20{ }^{\circ} \mathrm{C}$ (Zalar and Gunde-Cimerman, 2014) and altitudes close to 4000 m.a.s.l. (Buzzini et al., 2012). The areas where the samples were taken fall within the characteristics mentioned as the Porcon pine forests. On the other hand, some studies reveal the presence of yeasts of the genus Rhodotorula in habitats with low $\mathrm{pH}$ levels and with the presence of heavy metal or fossil fuel residues (Muñoz-Silva et al., 2019; Gupta et al., 2016); which explains its presence in the sampled area of $\mathrm{El}$ Paraíso forests, located near a river contaminated with mining tailings.

For molecular identification, the universal primers ITS1 and ITS4 were used, which can be directed to the conserved 18S, 5.8S, and 28S rDNA sequences, to be able to amplify the ITS1 and ITS2 regions, which vary according to the species depending on the length and sequence of the amplicon (Fujita et al., 2001). The ITS encoded regions deposited in public databases such as GenBank are the most widely used (Toju et al., 2012).
Regarding the maximum values of $A$ reached in the three strains of Rhrodotorula using the MS-2-7 (C/N 2:1), which yielded higher values than with the MS-1-7 medium ( $\mathrm{C} / \mathrm{N} 100: 1)$, there is information that a $\mathrm{C} / \mathrm{N}$ ratio greater than 20 does not produce a significant increase in biomass, but does stimulate yeast lipid biosynthesis. Lower $\mathrm{C} / \mathrm{N}$ ratios influence cell growth because the available forms of carbon and nitrogen are used mainly to satisfy cells' multiplication and development needs. Therefore, when nitrogen availability is reduced in the medium (MS-1-7), the growth rate decreases and the excess carbon is used to synthesize lipids as a storage substance (Ratledge, 2002; Kot et al., 2019).

The Gompertz model has been used to evaluate the growth kinetics of oleaginous yeasts strains, obtaining $\mathrm{R}^{2}$ values between 0.96 and 0.99 for Lipomyces starkeyi and Pichia pastoris, respectively (Sierra, 2013; Chang et al., 2006). In the present study, three Rhrodotorula strains showed an $\mathrm{R}^{2}$ of 0.98 to 0.99 , which indicates that the model fits with the experimental values up to a maximum stationary phase, equally in media with $\mathrm{C} / \mathrm{N} \mathrm{2:1}$ and 100:1.

A longer time to reach high $A$ values as observed in the three strains of Rhrodotorula using the C/N 2:1 medium has resulted in lower $\mu_{\max }$ values concerning the $\mathrm{C} / \mathrm{N}$ 100:1 medium. This aspect, as mentioned, can be influenced by a lower value of C/N (Kot et al., 2019).

Research has shown that oleaginous yeasts do not have an overactive fatty acid biosynthesis system but can produce significant amounts of acetyl-CoA, the basic unit for their biosynthesis (Papanikolaou and Aggelis, 2011), which is reflected in the processing time. It has been observed that the $\mathrm{C} / \mathrm{N}$ ratio influences the value of $\lambda$. Thus a 100:1 C/N ratio allows a rapid adaptation with a lower value of $\lambda$ and a higher value of $\mu_{\max }$ with an immediate and more extraordinary transformation to lipids. (Fig. 2, 3, 4, and 5). But the carbon source is very important; in $R$. glutinis, it has been reported that high production of lipids can reach $66.0 \%$ using glucose as a carbon source (Kot et al., 2016). An aspect considered is xylose used carbon source in the medium with a $\mathrm{C} / \mathrm{N}$ ratio of $100: 1$, while glucose was used as a carbon source in the medium with a $\mathrm{C} / \mathrm{N}$ ratio $2: 1$. In this regard, it has been reported that the $R$. glutinis strain T216 produced $36.6 \%$ of lipids, whose optimal conditions occurred when glucose was used as a carbon source, accumulating a higher concentration of lipids of $49.25 \%$ concerning the cellular biomass (Dai et al., 2007). Glucose and xylose can be used by oily yeasts isolated from soil or other natural sources to produce lipids. Still, glucose is the preferred sugar for any oily yeasts, and high $\mathrm{C} / \mathrm{N}$ ratios favor higher production. For xylose metabolism, yeast must be able to absorb pentose into the cell via sugar transporters. The overexpression of three regulatory enzymes (xylose 
reductase, xylitol dehydrogenase, and xylulokinase) can aid yeast growth (Sreeharsha and Mohan, 2020), and this is an aspect that may have favored $R$. mucilaginosa and $R$. kratochvilovae at a lower value of $\lambda$.

Studies show a more significant accumulation of lipids by yeast $R$. kratochvilovae and $R$. glutinis in a limiting nitrogen medium (Jiru et al., 2017; Yen et al., 2019), in line with findings shown in Fig. 5 for the Rhrodotorula strains with C/N 100:1. The accumulation of lipids in a culture with a deficiency of nitrogen is used for protein synthesis and cell growth. Still, when rapidly depleted, cells enter a state of survival in which they must increase their reserve materials, transforming the substrate into fats (Meesters et al., 1996). Similar results to the present investigation have also been obtained with $R$. kratochvilovae using a culture medium with a $40: 1 \mathrm{C} / \mathrm{N}$ ratio, resulting in $20.2 \%$ lipid content. In comparison, in a medium with a $\mathrm{C} / \mathrm{N}$ ratio of $120: 1$, they obtained a lipid content of $42.5 \%$ (Jiru et al., 2017). Likewise, for $R$. glutinis there is a consensus that lipid production is stimulated and increases at high $\mathrm{C} / \mathrm{N}$ ratios, which are formed in the secondary metabolism of yeast using acetyl CoA as a precursor. In this regard, a $\mathrm{C} / \mathrm{N} \mathrm{20:1}$ ratio has been equally used with amounts of glucose $16.2 \mathrm{~g} \mathrm{~L}^{-1}\left(\mathrm{NH}_{4}\right)_{2} \mathrm{SO}_{4} 1.0 \mathrm{~g} \mathrm{~L}^{-1}$, obtaining a low biomass production and total lipid content. When using glucose $57.0 \mathrm{~g} \mathrm{~L}^{-1} /\left(\mathrm{NH}_{4}\right)_{2} \mathrm{SO}_{4} 4.885 \mathrm{~g} \mathrm{~L}^{-1}$, high biomass production stimulated by the amount of nitrogen has been obtained. With high $\mathrm{C} / \mathrm{N}$ ratios $70: 1$ and $120: 1$ (glucose $57 \mathrm{~g} \mathrm{~L}^{-1} /\left(\mathrm{NH}_{4}\right)_{2} \mathrm{SO}_{4} 1.0 \mathrm{~g} \mathrm{~L}^{-1}$, and glucose 97.4 $\mathrm{g} \mathrm{L}^{-1} /\left(\mathrm{NH}_{4}\right)_{2} \mathrm{SO}_{4} 1.0 \mathrm{gL}^{-1}$, high values of total lipids and biomass at the maximum stationary phase in cultures with $R$. glutinis have been achieved.

It should be noted that an increase in the $\mathrm{C} / \mathrm{N}$ ratio $70: 1$ to an intermediate ratio of 100:1 results in a curb in the increase in total lipids, producing even a slight decrease (Braunwald et al., 2013). On the other hand, it has been shown that $R$. toruloides can present an efficient biomass production and storage lipids accumulation in nitrogen-rich media, provided that phosphorus or sulfate is the limiting factor of cell growth. According to what was stated above, it is shown that high values of biomass and lipid content can be obtained. One aspect to be highlighted is observed in Fig. 5, noting that Rhrodotorula cultures in media with $\mathrm{C} / \mathrm{N} 2$ : 1 ratio can provide lower lipid content, between $13 \%$ to $28 \%$, concerning C/N 100:1 medium, but when achieving a more significant amount of biomass, the lipids yield was higher $\left(4.65,5.59\right.$ and $8.80 \mathrm{~g} \mathrm{~L}^{-1)}$ in R. glutinis, R. mucilaginosa and $R$. kratochvilovae respectively, using glucose as a carbon source, noticeably with $R$. kratochvilovae. The present investigation has been carried beyond the maximum stationary phase to the logarithmic death phase, but it could not exceed the maximum growth process escalation. Another aspect to consider is the appropriate $\mathrm{C} / \mathrm{N}$ ratio and the amounts of the components that contribute carbon and nitrogen, coming from different substrate sources and the type of oil yeast (Karamerou and Webb, 2019). It is recommended to avoid the Cabtree effect caused by a high carbon concentration (Christophe et al., 2012; Braunwald et al., 2013).

\section{Conclusion}

Oleaginous yeasts were isolated and identified from the North Peruvian Andes with a greater than 20\% lipid content: Rhodotorula glutinis, $R$. mucilaginosa, and $R$. kratochvilovae. The $\mathrm{C} / \mathrm{N}$ ratio in the culture medium influenced the oleaginous yeasts kinetics, modeled with the parameterized Gompertz type II equation. Also, C/N affects biomass and lipid yields. With MS-1-7 (C/N 100:1) with xylose as carbon source, limiting nitrogen, a high $\mu_{\max }$ was obtained, reaching the stationary phase between 6 to $9 \mathrm{~h}$, as well as lipid accumulation between $23.1 \%$ and $31.5 \%$. With the MS-2-7 medium (C/N 2:1) with glucose as a carbon source, non-limiting nitrogen obtained the maximum biomass value in the stationary phase between 37 and $51 \mathrm{~h}$, which generated the highest biomass yield at the end of the whole process with a lipid yield of $4.65 ; 5.59$ and $8.80 \mathrm{~g} \mathrm{~L}^{-1}$. There is potential to obtain high lipid yields using a culture media nonlimiting nitrogen, examining not only the $\mathrm{C} / \mathrm{N}$ ratio. But also, the quantities, nature of the components, and type of oleaginous yeasts taking care to avoid a high carbon concentration to prevent the Crabtree effect.

\section{ACKNOWLEDGEMENTS}

To the National Council of Science, Technology and Technological Innovation (CONCYTEC) and Active Science of Peru, for providing the resources that allowed the realization of this research (Agreement $\mathrm{N}^{\circ}$ 165-2017-FONDECYT).

\section{Conflict of interest}

The authors declare that they have no conflict of interest.

\section{REFERENCES}

1. Adrio, J.L. (2017). Oleaginous yeasts: Promising platforms for the production of oleochemicals and biofuels. Biotechnology and Bioengineering, 114(9), 1915-1920. https:// doi.org/10.1002/bit.26337

2. Ageitos, J.M., Vallejo, J.A., Veiga-Crespo, P., \& Villa, T.G. (2011). Oily yeasts as oleaginous cell factories. Applied Microbiology and Biotechnology, 90(4), 1219-1227. https://doi.org/10.1007/s00253-011-3200-z

3. Braunwald, T., Schwemmlein, L., Graeff-Hönninger, S., French, W.T., Hernandez, R., Holmes, W.E., \& Claupein, W. (2013). Effect of different $\mathrm{C} / \mathrm{N}$ ratios on carotenoid and lipid production by Rhodotorula glutinis. Applied Microbiol- 
ogy and Biotechnology, 97(14), 6581-6588. https:// doi.org/10.1007/s00253-013-5005-8

4. Buzzini, P., Branda, E., Goretti, M., \& Turchetti, B. (2012). Psychrophilic yeasts from worldwide glacial habitats: diversity, adaptation strategies and biotechnological potential. FEMS Microbiology Ecology, 82(2), 217-241. https:// doi.org/10.1111/j.1574-6941.2012.01348.x

5. Chang, S.W., Shieh, C.J., Lee, G.C., Akoh, C.C., \& Shaw, J.F. (2006). Optimized Growth Kinetics of Pichia pastoris and Recombinant Candida rugosa LIP1 Production by RSM. Journal of Molecular Microbiology and Biotechnology, 11(1-2), 28-40. https://doi.org/10.1159/000092817

6. Christophe, G., Kumar, V., Nouaille, R., Gaudet, G., Fontanille, P., Pandey, A., Socco, C.R., \& Larroche, C (2012). Recent developments in microbial oils production: a possible alternative to vegetable oils for biodiesel without competition with human food? Brazilian Archives of Biology and Technology, 55(1), 29-46. https:// doi.org/10.1590/s1516-89132012000100004

7. Dai, C. C., Tao, J., Xie, F., Dai, Y. J., \& Zhao, M. (2007) Biodiesel generation from oleaginous yeast Rhodotorula glutinis with xylose assimilating capacity. African Journal of Biotechnology, 6(18), 2130-2134. https://doi.org/10.58 97/ajb2007.000-2331

8. Dey, P., \& Maiti, M.K. (2013). Molecular characterization of a novel isolate of Candida tropicalis for enhanced lipid production. Journal of Applied Microbiology, 114(5), 13571368. https://doi.org/10.1111/jam.12133

9. Fujita, S.I., Senda, Y., Nakaguchi, S., \& Hashimoto, T. (2001). Multiplex PCR Using Internal Transcribed Spacer 1 and 2 Regions for Rapid Detection and Identification of Yeast Strains. Journal of Clinical Microbiology, 39(10), 3617-3622. https://doi.org/10.1128/jcm.39.10.3617-3622.2 001

10. Gientka, I., Kieliszek, M., Jermacz, K., \& Błażejak, S. (2017). Identification and Characterization of Oleaginous Yeast Isolated from Kefir and Its Ability to Accumulate Intracellular Fats in Deproteinated Potato Wastewater with Different Carbon Sources. Biomed Research International, 2017, 1-19. https://doi.org/10.1155/2017/6061042

11. Gupta, A., Joia, J., Sood, A., Sood, R., Sidhu, C., \& Kaur, G. (2016). Microbes as Potential Tool for Remediation of Heavy Metals: A Review. Journal of Microbial \& Biochemical Technology, 8(4). https://doi.org/10.4172/1948-594 8.1000310

12. Jiru, T.M., Groenewald, M., Pohl, C., Steyn, L., Kiggundu, N., \& Abate, D. (2017). Optimization of cultivation conditions for biotechnological production of lipid by Rhodotorula kratochvilovae (syn, Rhodosporidium kratochvilovae) SY89 for biodiesel preparation. 3 Biotech, 7(2). https://doi.org/10.1007/s13205-017-0769-7

13. Karamerou, E.E., \& Webb, C. (2019). Cultivation modes for microbial oil production using oleaginous yeasts $-A$ review. Biochemical Engineering Journal, 151, 107322. https://doi.org/10.1016/j.bej.2019.107322

14. Kot, A.M., Błażejak, S., Kurcz, A., Gientka, I., \& Kieliszek, M. (2016). Rhodotorula glutinis-potential source of lipids, carotenoids, and enzymes for use in industries. Applied Microbiology and Biotechnology, 100(14), 6103-6117. https://doi.org/10.1007/s00253-016-7611-8

15. Kot, A.M., Błażejak, S., Kieliszek, M., Gientka, I., \& Bryś, J. (2019). Simultaneous Production of Lipids and Carote- noids by the Red Yeast Rhodotorula from Waste Glycerol Fraction and Potato Wastewater. Applied Biochemistry and Biotechnology, 189(2), 589-607. https:// doi.org/10.1007/s12010-019-03023-z

16. Lopes, H.J.S., Bonturi, N., Kerkhoven, E.J., Miranda, E.A., \& Lahtvee, P.J. (2020). C/N ratio and carbon sourcedependent lipid production profiling in Rhodotorula toruloides. Applied Microbiology and Biotechnology, 104 (6), 2639-2649. https://doi.org/10.1007/s00253-020-10386-5

17. Maina, S., Pateraki, C., Kopsahelis, N., Paramithiotis, S., Drosinos, E.H., Papanikolaou, S., \& Koutinas, A. (2016). Microbial oil production from various carbon sources by newly isolated oleaginous yeasts. Engineering in Life Sciences, 17(3), 333-344. https://doi.org/10.1002/elsc.2015 00153

18. Meesters, P.A.E.P., Huijberts, G.N.M., \& Eggink, G. (1996). High-cell-density cultivation of the lipid accumulating yeast Cryptococcus curvatus using glycerol as a carbon source. Applied Microbiology and Biotechnology, 45 (5), 575-579. https://doi.org/10.1007/s002530050731

19. Muñoz-Silva, L., Olivera-Gonzales, P., Santillán-Torres, M., \& Tamariz-Angeles, C. (2019). Microorganismos tolerantes a metales pesados del pasivo minero Santa Rosa, Jangas (Perú). Revista Peruana de Biología, 26(1), 109118. https://doi.org/10.15381/rpb.v26i1.15914

20. Papanikolaou, S., \& Aggelis, G. (2011). Lipids of oleaginous yeasts. Part I: Biochemistry of single cell oil production. European Journal of Lipid Science and Technology, 113(8), 1031-1051. https://doi.org/10.1002/ejlt.201100014

21. Patel, A., Karageorgou, D., Rova, E., Katapodis, P., Rova, U., Christakopoulos, P., \& Matsakas, L. (2020). An Overview of Potential Oleaginous Microorganisms and Their Role in Biodiesel and Omega-3 Fatty Acid-Based Industries. Microorganisms, 8(3), 434. https://doi.org/10.3390/ microorganisms 8030434

22. Ratledge, C. (2002). Regulation of lipid accumulation in oleaginous microorganisms. Biochemical Society Transactions, 30(6), 1047-1050. https://doi.org/10.1042/ bst0301047

23. Sierra, R.V. (2013). Produção de leveduras oleaginosas em meio de cultura contendo hidrolisado de bagaço de cana-de-açúcar. Repositorio. unicamp.br. http:// repositorio.unicamp.br/bitstream/REPOSIP/266600/1/ SierraAristizabal_RuthVeronica_M.pdf.

24. Sitepu, I.R., Sestric, R., Ignatia, L., Levin, D., German, J.B., \& Gillies, L.A., Almada, L.A.G., \& Boundy-Mills, K.L. (2013). Manipulation of culture conditions alters lipid content and fatty acid profiles of a wide variety of known and new oleaginous yeast species. Bioresource Technology, 144, 360-369. https://doi.org/10.1016/j.biortech.2013.0 6.047

25. Sitepu, I.R., Garay, L.A., Sestric, R., Levin, D., Block, D.E., German, J.B., \& Boundy-Mills, K.L. (2014). Oleaginous yeasts for biodiesel: Current and future trends in biology and production. Biotechnology Advances, 32(7), 1336-1360. https://doi.org/10.1016/j.biotechadv.2014.08.0 03

26. Sláviková, E., \& Vadkertiová, R. (2000). The occurrence of yeasts in the forest soils. Journal of Basic Microbiology, 40(3), 207-212. https://doi.org/10.1002/1521-4028 (200007)40:3<207::aid-jobm207>3.0.co;2-h

27. Spagnuolo, M., Yaguchi, A., \& Blenner, M. (2019). Oleagi- 
nous yeast for biofuel and oleochemical production. Current Opinion in Biotechnology, 57, 73-81. https:// doi.org/10.1016/j.copbio.2019.02.011

28. Sreeharsha, R.V., \& Mohan, S.V. (2020). Obscure yet Promising Oleaginous Yeasts for Fuel and Chemical Production. Trends in Biotechnology, 38(8), 873-887. https:// doi.org/10.1016/j.tibtech.2020.02.004

29. Tchakouteu, S.S., Chatzifragkou, A., Kalantzi, O., Koutinas, A.A., Aggelis, G., \& Papanikolaou, S. (2014). Oleaginous yeast Cryptococcus curvatus exhibits interplay between biosynthesis of intracellular sugars and lipids. European Journal of Lipid Science and Technology, 117(5), 657-672. https://doi.org/10.1002/ejlt.201400347

30. Tjørve, K.M.C., \& Tjørve, E. (2017). The use of Gompertz models in growth analyses, and new Gompertz-model approach: An addition to the Unified-Richards family. PLOS ONE, 12(6), e0178691. https://doi.org/10.1371/ journal.pone.0178691

31. Toju, H., Tanabe, A.S., Yamamoto, S., \& Sato, H. (2012). High-Coverage ITS Primers for the DNA-Based Identification of Ascomycetes and Basidiomycetes in Environmental Samples. Plos ONE, 7(7), e40863. https:// doi.org/10.1371/journal.pone.0040863

32. Vasconcelos, B., Teixeira, J.C., Dragone, G., \& Teixeira, J.A. (2019). Oleaginous yeasts for sustainable lipid production-from biodiesel to surf boards, a wide range of "green" applications. Applied Microbiology and Biotechnology, 103(9), 3651-3667. https://doi.org/10.1007/s00253- 019-09742-x

33. Wuczkowski, M., \& Prillinger, H. (2004). Molecular identification of yeasts from soils of the alluvial forest national park along the river Danube downstream of Vienna, Austria ("Nationalpark Donauauen"). Microbiological Research, 159(3), 263-275. https://doi.org/10.1016/j.micre s.2004.05.001

34. Yen, H.W., Palanisamy, G., \& Su, G.C. (2019). The Influences of Supplemental Vegetable Oils on the Growth and $\beta$-carotene Accumulation of Oleaginous YeastRhodotorula glutinis. Biotechnology and Bioprocess Engineering, 24(3), 522-528. https://doi.org/10.1007/s12257019-0027-4

35. Yurkov, A.M., Kemler, M., \& Begerow, D. (2012). Assessment of yeast diversity in soils under different management regimes. Fungal Ecology, 5(1), 24-35. https:// doi.org/10.1016/j.funeco.2011.07.004

36. Zalar P., Gunde-Cimerman N. (2014) Cold-Adapted Yeasts in Arctic Habitats. In: Buzzini P., Margesin R. (eds) Cold-adapted Yeasts (pp. 49-74). Springer, Berlin, Heidelberg. https://doi.org/10.1007/978-3-642-39681-6_3

37. Zarli, A. (2020). Oleochemicals: all time players of green chemistry. Studies in Surface Science and Catalysis, 7795. https://doi.org/10.1016/B978-0-444-64337-7.00006-9

38. Zhang, Y., Nielsen, J., \& Liu, Z. (2021). Yeast based biorefineries for oleochemical production. Current Opinion in Biotechnology, 67, 26-34. https://doi.org/10.1016/j.copb io.2020.11.009 